http://ojs.stikes-muhammadiyahku.ac.id/index.php/herbapharma

\title{
UJI AKTIVITAS ANTIBAKTERI EKSTRAK BATANG BUAH NAGA (Hylocereus polyrhizus (F.A.C.Weber) Britton \& Rose) TERHADAP Staphylococcus aureus
}

\section{Monita Leviyanti", Sukmawati}

Program Studi Farmasi, STIKes Muhammadiyah Kuningan

*E-mail : Monita.levi99@gmail.com

\begin{abstract}
ABSTRAK
Batang buah naga merupakan limbah dari tanaman buah naga yang mengandung senyawa flavonoid, saponin dan steroid. Penelitian lebih lanjut terhadap batang buah naga diperlukan agar dapat memaksimalkan pemanfaatannya. Penelitian ini bertujuan untuk menguji aktivitas antibakteri batang buah naga terhadap bakteri Staphylococcus aureus. Ekstraksi sampel batang buah naga menggunakan metode maserasi dengan etanol $70 \%$. Konsentrasi ekstrak buah naga dibuat menjadi 25\%, 50\%, 75\%, dan 100\%. Aquadest sebagai kontrol negatif dan cefixime sebagai kontrol positif. Bakteri dibiakan pada media MHA menggunakan teknik spread plate, cakram yang telah direndam zat uji ditanamkan pada media. Hasil penelitian menunjukan bakteri sensitif terhadap kontrol positif sedangkan pada konsentrasi ekstrak tidak menunjukan adanya zona hambat yang terbentuk pada semua sehingga diketahui bahwa ekstrak batang buah naga tidak memiliki aktivitas antibakteri
\end{abstract}

Kata Kunci: Batang buah naga, Staphylococcus aureus, Uji Aktivitas

\begin{abstract}
Dragon fruit stems are waste from dragon fruit plants which contain flavonoid compounds, saponins and steroids. Further research on dragon fruit stems is needed in order to maximize its utilization. This study aimed to test the antibacterial activity of dragon fruit stems against Staphylococcus aureus bacteria. Extraction of dragon fruit stem samples using maceration method with $70 \%$ ethanol. The concentration of dragon fruit extract was made into $25 \%, 50 \%, 75 \%$, and $100 \%$. Aquadest as a negative control and cefixime as a positive control. Bacteria were cultured on MHA media using the spread plate technique, discs that had been soaked in the test substance were implanted in the media. The results showed that the bacteria were sensitive to positive control while the concentration of the extract did not show any inhibition zones formed in all so that it was known that the dragon fruit stem extract did not have antibacterial activity.
\end{abstract}

Keywords : Dragon fruit stem, Staphylococcus aureus, Activity Tes 


\section{PENDAHULUAN}

Tanaman buah naga merupakan tanaman yang berasal dari Amerika memiliki rupa seperti kaktus, tanaman ini tumbuh subur di dataran Indonesia sehingga banyak dibudidayakan untuk diambil buahnya dan dipasarkan pada masyarakat. Terdapat berbagai penelitian yang membuktikan bahwa setiap bagian tanaman buah naga memiliki kandungan senyawa yang bermanfaat. Penelitian pada ekstrak buah naga merah terbukti mengandung flavonoid (Jalmi, 2014). Selain buahnya berdasarkan penelitian yang dilakukan oleh Oriana (2020) diketahui senyawa yang terkandung pada kulit buah naga merah yaitu alkaloid, tanin, flavonoid, dan steroid. Penelitian lain menyatakan bahwa berdasarkan uji aktivitas hambat mikroba diketahui ekstrak kulit buah naga merah memiliki aktivitas antimikroba terhadap bakteri E. coli (Sartika et al., 2019). Penelitian yang dilakukan oleh Anggraini et al (2017) menyatakan bahwa berdasarkan rata-rata zona hambat yang terbentuk ekstrak kulit buah naga putih (Hylocereus undatus (Haw.) Britton \& Rose) memiliki kekuatan daya hambat terhadap bakteri Staphylococcus epidermidis dalam kategori kuat. Penelitian terhadap kulit buah naga menyatakan bahwa Fraksi n-heksan kulit buah naga merah memiliki aktivitas antibakteri pada bakteri Staphylococcus aureus (Wahdaningsih et al., 2014).

Bakteri merupakan mikroorganisme yang tidak terlihat oleh mata telanjang, ia ada di manamana dan dapat menempel baik pada benda ataupun makanan. Sebagian dari mereka merugikan manusia dengan menimbulkan penyakit. Salah satunya bakteri Staphylococcus merupakan penyebab utama dari infeksi yang didapat di rumah sakit dan infeksi komunitas.

Dengan banyaknya penelitian terhadap kandungan senyawa maupun aktivitas dari buah naga baik itu kulit ataupun dagingnya membuktikan bahwa setiap bagian dari buah naga memiliki manfaat. Selain buah dan kulit buah naga terdapat batang buah naga yang memiliki kandungan senyawa bermanfaat hal ini terbukti oleh penelitian yang dilakukan oleh Sulistyarini et al (2016) diketahui bahwa batang buah naga (Hylocereus polyrhizus (F.A.C.Weber) Britton \& Rose) mengandung steroid, flavonoid dan saponin yang terdapat dalam serbuk, ekstrak, fraksi n-heksan dan fraksi etil asetat sedangkan steroid tidak terkandung dalam fraksi air. Batang buah naga merupakan bagian tumbuhan yang sering dipangkas kemudian dibuang begitu saja, telah terdapat pemanfaatan terhadap batang buah naga yang diubah menjadi tepung. Penelitian lebih lanjut terhadap batang buah naga diperlukan agar dapat dimanfaatkan dengan baik dan mencegah batang buah naga menjadi limbah.

Berdasarkan uraian di atas maka saya sebagai peneliti akan melakukan uji aktivitas antibakteri ekstrak batang buah naga (Hylocereus polyrhizus (F.A.C.Weber) Britton \& Rose) terhadap Staphylococcus aureus.

\section{BAHAN DAN METODE}

\section{Bahan dan Alat}

Bahan yang digunakan yaitu batang buah naga, antibiotik cefixime, isolat bakteri Staphylococcus aureus, MHA (Mueller Hinton Agar), $\mathrm{NaCl} 0,9 \%$, Etanol 70\%, standar McFarland, $\mathrm{H}_{2} \mathrm{SO}_{4} 1 \%, \mathrm{BaCl}_{2}$ $1 \%$.

Alat yang digunakan yaitu gelas ukur (Herma), erlenmeyer (Approx), batang pengaduk (Pyrex), corong kaca (Herma), cawan petri (Herma), pipet tetes, jarum ose, kertas saring (Rofa), pinset, mistar (XP tool), beaker glass (Herma), lampu spirtus, cawan porselen, tabung reaksi, timbangan analitik (Shimadzu ATX224), inkubator (Memmert), autoclave, watterbath, pipet volume, alumunium foil (Klinpak) dan termometer. 


\section{Jenis Penelitian}

Penelitian ini merupakan penelitian eksperimental. Pada penelitian dilakukan pengamatan terhadap zona hambat yang terbentuk dari ekstrak batang buah naga terhadap Staphylococcus aureus.

\section{Lokasi dan Waktu Penelitian}

Penelitian dilakukan di Laboratorium Farmasetika dan Komunitas STIKes Muhammadiyah Kuningan pada Bulan Maret 2021.

\section{Prosedur Penelitian}

\section{a. Pengolahan Sampel}

Sampel batang buah naga diambil di Desa Cikadu, Kuningan Jawa Barat yang selanjutnya untuk mengetahui kebenaran tanaman dideterminasi di Laboratorium STIKes Muhammadiyah Kuningan.

Batang buah naga segar kemudian disortasi lalu cuci untuk menghilangkan kotoran yang menempel selanjutnya perkecil ukuran batang buah naga sehingga mempermudah proses pengeringan oleh sinar matahari.

\section{b. Pembuatan Ekstrak}

Metode yang digunakan untuk membuat ekstrak yaitu maserasi dengan pelarut etanol $70 \%$. Metode maserasi dapat menjaga senyawa bersifat termolabil tidak rusak (Mukhriani, 2014). Serbuk batang buah naga sebanyak $250 \mathrm{gr}$ dimasukan ke dalam toples kaca dan tambahkan pelarut etanol $70 \%$ hingga serbuk terendam dengan dilakukan pengadukan sesekali, setelah 24 jam saring menggunakan kain flanel kemudian lakukan 2 kali remaserasi pada residu. Uapkan hasil maserasi dan remaserasi menggunakan waterbath sehingga ekstrak yang diperoleh menjadi kental.

\section{c. Pembuatan Media MHA (Mueller Hinton Agar)}

Pembuatan media dilakukan dengan melarutkan $19 \mathrm{gr}$ MHA dengan $500 \mathrm{~mL}$ aquadest kemudian homogenkan di dalam erlenmeyer dan dipanaskan diatas lampu spiritus hingga homogen, sterilkan media menggunakan autoklaf pada suhu $121^{\circ} \mathrm{C}$ selama 15 menit dengan tekanan $1 \mathrm{~atm}$ (Febrianasari, 2018).

\section{d. Pembuatan Inokulum Bakteri}

Bakteri Staphylococcus aureus diperoleh dari Universitas Padjadjaran yang sebelumnya telah dilakukan peremajaan bakteri pada media MHA diambil 2-3 koloni menggunakan jarum ose kemudian masukan kedalam tabung reaksi yang ditambahkan $\mathrm{NaCl} 0,9 \%$ sebanyak $10 \mathrm{~mL}$ dan homogenkan hingga kekeruhannya sama dengan larutan standar Mc Farland 0,5.

\section{e. Pembuatan Konsentrasi Ekstrak}

Ekstrak batang buah naga pekat diencerkan dengan konsentrasi $25 \%, 50 \%, 75 \%$, dan $100 \%$ kemudian tambahkan aquadest hingga $10 \mathrm{~mL}$ 


\section{f. Pembuatan Larutan Kontrol}

Larutan kontrol positif dibuat dengan melarutkan gr cefixime dengan $10 \mathrm{~mL}$ aquadest. Sedangkan larutan kontrol negatif yang dipakai yaitu aquadest.

\section{g. Uji Aktivitas}

Inokulum bakteri yang telah dibuat sebelumnya diinokulasikan pada media MHA menggunakan cotton bud dengan teknik gores. Cakram steril yang terbuat dari kertas saring direndam dengan ekstrak batang buah naga serta larutan kontrol kemudian ditanamkan pada media MHA yang telah ditanami bakteri menggunakan pinset. Inkubasi selama 24 jam dengan suhu $37^{\circ} \mathrm{C}$ lalu ukur zona hambat yang terbentuk menggunakan mistar.

\section{Analisis Data}

Pengambilan data pada penelitian ini dilakukan dengan menamai data dengan kode tertentu yang kita buat dapat berupa huruf ataupun angka (coding), data yang telah didapat kemudian dimasukan kedalam tabel yang telah penulis buat (tabulating).

\section{HASIL DAN PEMBAHASAN}

Pembuatan ekstrak dengan maserasi dan 2 kali remasersi menggunakan etanol $70 \%$ sebagai pelarut karena etanol $70 \%$ merupakan pelarut bersifat polar yang dapat menarik senyawa metabolit sekunder dengan aktivitas antibakteri lebih baik dibanding etanol $96 \%$ dan etanol 50\% (Mubarak et al, 2018). Rendemen yang dihasilkan yaitu $31,152 \%$. Rendemen yang baik yaitu jika nilainya lebih dari $10 \%$ maka rendemen ekstrak batang buah naga termasuk kategori baik karena nilainya lebih dari $10 \%$.

Pada uji aktivitas cakram yang telah disterilkan dengan oven selama 1 jam dengan suhu $181^{\circ} \mathrm{C}$ direndam pada larutan konsentrasi ekstrak $25 \%, 50 \%, 75 \%$, dan $100 \%$ serta larutan kontrol positif dan negatif ditanamkan pada media MHA yang telah ditanami bakteri menggunakan pinset, penanaman ini dilakukan di dekat api bunsen sehingga area tetap steril. Media MHA merupakan media yang dapat ditumbuhi semua bakteri karena bukan media diferensial dan media selektif, selain itu media ini mendukung bakteri non-fastidious yang patogen dapat tumbuh (Atmojo, 2016). Inkubasi selama 24 jam pada suhu $37^{\circ} \mathrm{C}$ kemudian ukur zona hambat yang terbentuk menggunakan mistar

Tabel 1. Hasil Pengukuran Diameter Zona Hambat

\begin{tabular}{|c|c|c|c|c|c|c|}
\hline \multirow{3}{*}{ Perlakuan } & \multicolumn{6}{|c|}{ Diameter zona hambat (mm) } \\
\hline & \multicolumn{4}{|c|}{ Konsentrasi } & \multicolumn{2}{|c|}{ Kontrol } \\
\hline & $25 \%$ & $50 \%$ & $75 \%$ & $100 \%$ & Positif & Negatif \\
\hline 1 & 0 & 0 & 0 & 0 & 24 & 0 \\
\hline 2 & 0 & 0 & 0 & 0 & 24 & 0 \\
\hline 3 & 0 & 0 & 0 & 0 & 30 & 0 \\
\hline 4 & 0 & 0 & 0 & 0 & 24 & 0 \\
\hline
\end{tabular}

Berdasarkan tabel hasil pengukuran zona hambat di atas dapat diketahui bahwa terjadi perbedaan yang signifikan antara kontrol positif dengan kontrol negatif dan seluruh konsentrasi. Hal ini menandakan jika tidak adanya aktivitas antibakteri pada ekstrak batang buah naga 
Tabel 2. Standar Diameter Zona Hambat Menurut CLSI

\begin{tabular}{cccc}
\hline Antibiotik & S & I & I \\
\hline Cefixime & $\geq 19$ & $16-18$ & $\leq 15$ \\
\hline Ket & $\mathrm{S}=$ Suceptible & I = Intermidate & R = Resistant \\
\hline
\end{tabular}

Menurut CLSI ekstrak batang buah naga yang diuji terhadap Staphylococcus aureus memiliki kategori sensitif yang kuat karena zona hambat yang terbentuk lebih dari $19 \mathrm{~mm}$. Tidak adanya aktivitas antibakteri ekstrak batang buah naga pada penelitian ini berbanding terbalik dengan penelitian yang dilakukan oleh Ritarwan \& Nerdy (2018) bahwa adanya aktivitas antibakteri batang buah naga terhadap bakteri penyebab meningitis. Clinical and Laboratory Standards Institute (CLSI) (2012) menyebutkan faktor yang mempengaruhi aktivitas antibakteri yaitu faktor biologis yang tidak dapat dikendalikan dan faktor teknis yang masih dapat dikendalikan. Faktor teknis dalam penelitian ini yaitu penguapan ektsrak yang suhunya tidak terkontrol dengan baik sehingga senyawa yang tidak tahan panas rusak atau menghilang dari ekstrak diketahui bahwa saponin merupakan senyawa yang rentan terhadap suhu yang tinggi (Muflihah, 2015) dan flavonoid merupakan senyawa yang mudah teroksidasi pada suhu tinggi (Rompas et al, 2012), hal lainya yaitu skrining fitokimia yang tidak dilakukan pada ekstrak sehingga zat yang terkandung di dalamnya tidak dapat dipastikan dengan baik. Faktor biologis dalam penelitian ini yaitu adanya korelasi antara kadar hambat minimum dengan kadar flavonoid total yang terkandung dalam ekstrak (Manik, 2014) sehingga tidak adanya aktivitas antibakteri pada ekstrak batang buah naga salah satu sebabnya diduga karena kadar senyawa flavonoid, steroid dan saponin yang terkandung di dalamnya rendah sehingga tidak cukup kuat untuk menghambat pertumbuhan staphylococcus aureus. Penelitian lain membuktikan bahwa fraksinasi mengoptimalkan daya hambat (Ndowo et al, 2011), perlu dilakukannya penelitian lanjutan dengan melakukan fraksinasi pada ekstrak batang buah naga yang akan diuji aktivitas antibakteri sehingga dapat diketahui senyawa yang paling bertanggung jawab terhadap aktivitas antibakteri. Berdasarkan hal tersebut tidak dilakukannya fraksinasi dapat menjadi salah satu sebab tidak adanya aktivitas ekstrak batang buah naga pada penelitian ini karena zat yang diuji tidak spesifik.

\section{SIMPULAN}

Dari uraian penelitian yang telah dipaparkan maka dapat disimpulkan bahwa hasil penelitian yaitu Ekstrak Batang Buah Naga (Hylocereus Polyrhizus (F.A.C.Weber) Britton \& Rose) tidak memiliki aktivitas antibakteri, karena tidak adanya zona hambat yang terbentuk.

\section{REFERENSI}

Anggraini, P, H., Fakhrurrazi and Harris, A. (2017) 'Uji Antibakterial Ekstrak Kulit Buah Naga Putih (Hylocereus undatus) Terhadap Bakteri Staphylococcus epidermidis', Jimvet, 01(3), pp. 416-423.

Febrianasari, F. (2018) Uji Aktivitas Antibakteri Ekstrak Daun Kirinyu (Chromolaena odorata) Terhadap Staphylococcus aureus. Yogyakarta, Univresitas Sanata Dharma.

La, E. O. J. et al. (2020) 'Skrining Fitokimia Dan Analisis Kromatografi Lapis Tipis Ekstrak Etanol Kulit Buah Naga Merah (Hylocereus polyrhizus)', Indonesian Journal of Pharmacy and Natural Product, 03(1), pp. 45-58.

Manik, D. F., Hertiani, T. \& Anshory, H., 2014. Analisis Korelasi Antara Kadar Flavonoid Dengan Aktivitas Antibakteri Ekstrak Etanol Dan Fraksi-fraksi Daun Kersen (Muntingia Calabura L.) Terhadap Staphylococcus Aureus. Khazanah : Jurnal Mahasiswa UII, VI(2), pp. 1-12. 
Muflihah, M. (2015) "Analisis Variasi Konsentrasi terhadap Uji Toksisitas Akut Golongan Senyawa Metabolit Sekunder dari Ekstrak Biji Pepaya (Carica papaya L.) pada Larva Udang (Artemia salina Leach)", Proceeding of Mulawarman Pharmaceuticals Conferences, 1(1), pp. 213221. doi: $10.25026 / \mathrm{mpc}$.v1i1.28.

Mukhriani (2014) 'Ekstraksi, pemisahan senyawa, dan identifikasi senyawa aktif', Jurnal of Pharmacy, 7(2), pp. 361-367.

Nwodo, U. U., Iroegbu, C. U., Ngene, A. A. \& Chigor, V. N., 2011. Effects of Fractionation and Combinatorial Evaluation of Tamarindus indica Fractions for Antibacterial Activity. molecules, Volume XVI, pp. 4818-4827.

Rompas, R. A., Edy, H. J. \& Yudistira, A., 2012. Isolasi Dan Identifikasi Flavonoid Dalam Daun Lamun (Syringodium Isoetifolium). Pharmacon, 1(2), pp. 59-63.

Sartika, D. et al. (2019) 'Identifikasi Senyawa Antimikroba Alami Pangan Pada Ekstrak Kulit Buah Naga Merah Dengan Menggunakan GC-MS', 24(2), pp. 67-76.

Sulistyarini, I., Sari Arum, D. and Wicaksono, T. (Sekolah T. I. F. "Yayasan P. S. (2019) 'Skrining Fitokimia Senyawa Metabolit Sekunder Batang Buah Naga... (Sulistyarini, dkk)', Jurnal Ilmiah Cendikia Ekstata, 5(9), pp. 56-62.

Wahdaningsih, S., Untari, E. K. and Fauziah, Y. (2014) 'Antibakteri Fraksi n-Heksana Kulit Hylocereus polyrhizus Terhadap Staphylococcus epidermidis dan Propionibacterium acnes', Pharmaceutical Sciences and Research, 1(3), pp. 180-193. doi: 10.7454/psr.v1i3.3490. 